\title{
The Impact of Mergers and Acquisitions on Service Quality of Banks in Ghana: Case Study of Ecobank and Access Bank Ghana
}

\author{
Johnson Yeboah ${ }^{1}$, Ernest K. Asirifi ${ }^{1} \&$ Samuel Ampadu ${ }^{2}$ \\ ${ }^{1}$ School of Business, Takoradi Polytechnic, Ghana \\ ${ }^{2}$ University of Ghana, Legon, Ghana \\ Correspondence: Johnson Yeboah, School of Business, Takoradi Polytechnic, Ghana. E-mail: \\ johnsonyeboah14@yahoo.com
}

Received: September 6, 2015

Accepted: October 21, 2015

Online Published: November 25, 2015

doi:10.5539/ijbm.v10n12p167

URL: http://dx.doi.org/10.5539/ijbm.v10n12p167

\begin{abstract}
Ghana has witnessed a wave of mergers and acquisitions ( $M$ \& As) in the banking industry following the bank recapitalization initiative by the government in 2008. This raises an important question concerning the trade-off between the possible efficiency gains and efficiency losses as banks merge into one large unit. The objective of this study was to find out how Mergers \& Acquisitions have impacted service quality of consolidated banks in Ghana. A descriptive and explanatory design was adopted as the study sought to describe customer perceived service quality and to also explain the relationship between M \& As and service quality. An ANOVA and T-tests techniques were used to analyze primary and secondary data gathered. Findings from the study indicated that $\mathrm{M}$ \& As had positive impact on overall service quality. The conclusion drawn by the researchers indicates that mergers and acquisitions offer superior growth and financing option for banks. This in turn promotes economic efficiency through improvements in costs and services delivery.
\end{abstract}

Keywords: Ghana, impact, mergers and acquisitions, service quality

\section{Introduction}

Commercial banks play crucial roles in the financial industry and the economy of Ghana. They contribute significantly to the efficiency of the money and capital markets through their intermediary role. Thus, an efficient economy is to a large extent driven by an efficient financial system which in turn is dependent on an efficient banking system.

Since 1988 successive governments of Ghana have undertaken financial sector reforms for the purpose of improving the efficiency of the financial system. An effect of these reforms has been a surge in mergers and acquisitions amongst Ghanaian commercial banks, particularly during the post-regulatory capital directive of 2008. The banking industry in Ghana had experienced only one M \& A; a merger between Social Security Bank (SSB) and National Savings and Credit Bank (NSCB) in 1994. After 2008 however three M \& As have been consummated, Ecobank (EBG) acquiring The Trust Bank (TTB), Access Bank acquiring Intercontinental bank, and Bank of Africa acquiring Amalgamated bank. This raises an important question concerning the trade-off between the possible efficiency gains (resulting from replacement of inefficient management, structures, processes, etc) and the possible efficiency losses (as a result of excessive exercise of market power, managerial turf battles, downsize disruptions, high associated costs, etc). If any improvements in efficiency from these mergers and acquisitions are large relative to their adverse effects then such consolidation may be in the interest of the public and should thus be encouraged by the government. It will also reinforce the finding that Regulation is the most important driver of change in Ghanaian banking industry (Banking Survey, 2012).

Prior to the reforms that began in 1988, there had been an extensive post-independence government ownership in the banking industry. All the banks that were set up between the early 1950s to the late 1980s were either wholly or majority-owned by the public sector. Interest rates were centrally controlled by the Monetary Authority and there were restrictions on sectarian credit allocation. According to Brownbridge et al. (1996), financial sector policies were characterized by severe financial repressions, real interest rates were steeply negative and most of the credit was channeled to the public sector. There were very few banks in the industry due to significant government ownership and heavy regulations that created 'insurmountable' barrier to entry. The range of 
financial products was narrow and industry competition was low Brownbridge et al., (1996). The result was on over regulated, unattractive and inefficient banking system which did not promote economic growth. The researchers therefore, sort to identify how Mergers and Acquisitions have impacted service quality in the Banking industry in Ghana.

\subsection{Statement of Problem}

Existing literature on bank efficiency in Ghana predominantly adopts financial indicators such as cost or profit efficiency. Non-financial factors which are said to offer a good guide; Umar and Olatunde (2011), particularly, when adopted in conjunction with financial indicators, can provide superior outcome.

This paper attempts to contribute to bridging this perceived gap by assessing the improvement or otherwise in service quality of selected Ghanaian Banks following $\mathrm{M} \& \mathrm{~A}$.

\subsection{Research Questions}

In order to gather and analyze relevant data, the following research questions were formulated to guide the study

- Are the banks in Ghana meeting the services quality needs of their customers after Mergers and Acquisitions?

- To what extent have the banks met the expectation of customers after M\&A?

- What are the perceptions of customers on service quality of the banks before and after Mergers and Acquisitions?

\subsection{Research Objectives}

The general objective of the study is to explore and establish the essence of Mergers and Acquisitions and its impact on service quality among the banks in Ghana. The specific objectives of the study are therefore to:

- Ascertain if the banks in Ghana are meeting the services quality needs of their customers after Mergers and Acquisitions.

- To evaluate the extent to which the banks have met the expectation of customers after M \& A.

- To examine the perception of customers on quality of service of the banks before and after Mergers and Acquisitions.

\subsection{Literature Review}

The chapter covers the literature reviewed on concepts, theories and types pertaining to mergers and acquisitions and service quality.

\subsection{Conceptual Definitions}

Merger and Acquisition literature is laden with usage of terms like merger, acquisition, takeover and amalgamation. Many authors classify them differently. A few arduously distinguish between each, whereas others use them synonymously. For example, (Weston, Chung, \& Hoag, 1996) recognize two forms of combinations- mergers and acquisitions (tender offers). Machiraju (2003) on the other hand uses merger as a broader term and considers acquisitions and takeovers as two of its type. Other works in the area classify combinations as mergers, acquisitions (takeovers) and hostile takeovers (tender offers are considered as one of the modus operandi for hostile takeovers.

According to Machiraju (2003, p. 1), 'merger is a broad term and it denotes the combination of two or more companies in such a way that only one survives while the other is dissolved. A merger is an investment in a future growth opportunity. In merger proposals plant is ready and market acceptance, clear and well established. When two companies differ significantly in size, they usually merge'. Weston, Chung and Hoag (1996, p. 4) define merger as, 'any transaction that forms one economic unit from two or more previous ones'. Mc Carthy (1963, p. 16) defines merger as, 'the combination of two or more business entities into a single economic enterprise.

\subsection{Acquisitions}

Acquisitions involve one company buying over all or a majority of the assets of another company Okonkwo, (2004). Acquisitions therefore put decision making authority into the hands of the acquiring company. Okonkwo (2004) explains that consolidation through acquisition means that the shareholders of the purchased firm are paid off, their ownership rights over assets and they cease to be owners of the new entity.

Acquisitions can result in two main outcomes: whether the acquired institutions are consolidated into one single 
institution or continue to operate as separate entities under new ownership (Pilloff \& Santomero, 1996). The undertaking of mergers result in the sharing of assets wherein the shareholders of both joining companies still retain some level of ownership in the new. Acquisitions on the other hand result in a complete change or handing over in the ownership structure of the new entity Okonkwo (2004).

According to Machiraju (2003, p. 2), 'the traditional acquisition is the negotiated acquisition in which a willing buyer and willing seller negotiate the terms under which an acquisition or merger occurs... Acquisition refers to a situation where one firm acquires another and the latter ceases to exist... A firm that attempts to acquire or merge with another company is called an acquiring company. A target company is a firm that is being solicited by the acquiring company. The assets of the dissolved firm would be owned by the acquiring company. The shareholders of the acquired company are paid either cash or given shares in acquiring company'. Mc Carthy (1963, p. 16) defines acquisition as, 'a number of so-called mergers involving exchanges of capital stocks legally are acquisitions, particularly where there are large number of shareholders involved. In such non-merger cases, one company "acquires" the voting stock of another solely in exchange of its voting stock. Acquisitions, in a legal sense, may also be effected for cash or cash equivalent, such as debt securities'. According to De Pamphilis (2001, p. 5), 'an acquisition occurs when one company takes a controlling stake in another firm, a legal subsidiary of another firm, or selected assets of another firm such as a manufacturing facility'.

\subsection{Theories of Mergers and Acquisitions}

Mergers and acquisitions is an aspect of corporate strategy and corporate finance that deals with the integration of different companies and similar entities that can help an enterprise grow rapidly in its sector or location of origin, or a new field or new location, without creating a subsidiary or using a joint venture Gaughan (2007).

Economists have promoted several competing theories of M\&As. Among them are empire-building (Baumol, 1967; Mueller, 1969), furthering anticompetitive activities, such as monopoly power (Roll, 1986; Mueller, 1993), management-entrenchment (Shleifer \& Vishny, 1989), and an overestimation of a manager's ability to improve the performance of a target he or she perceives to be underperforming (Roll, 1986).

The two leading M \& A efficiency theories are the disciplinary and synergistic merger motives: Disciplinary mergers theory suggests that M \& As discipline target firms' managers who pursue objectives other than profit maximization. Managers who do not maximize profits presumably would focus attention on goals other than profitability. Since this difference in focus can come at the expense of operating efficiency, a firm's performance may suffer. Poor performance does not go unnoticed, however. Opportunistic buyers may observe the poor performance accompanied by good assets and discipline the poorly performing plant by acquiring it. Thus, the disciplinary theory suggests that acquiring firms merge with poorly performing targets and improve their performance as new management realizes the full potential of a target's assets.

Synergistic mergers theory holds that firm managers achieve efficiency gains by combining an efficient target with their business and then improving the target's performance. Buyers recognize specific complementarities between their business and that of the target. Thus, even though the target is already performing well, it should perform even better when it is combined with its complementary counterpart, the buyer firm. The synergistic theory implies that target firms (or plants) perform well both before and after mergers.

\subsection{Types of Mergers}

Although merger and consolidation have been used interchangeably, there is a distinction between the two terms. According to Gaughan (2002) "A merger is a combination of two corporations in which only one corporation survives and the merged corporation goes out of existence. In a merger, the acquiring company assumes the assets and liabilities of the merged company. A merger differs from a consolidation, which is a business combination whereby two or more companies join to form an entirely new company. All of the combining companies are dissolved and only the new entity continues to operate". Lepetit et al. (2004) differentiated between merger and acquisition; they defined merger as a transaction when firm (A) (or entity) is merged with firm (B), subsequently the legal existence of one (at least) original entity is seized to exist. An acquisition, on the other hand, is considered to be a transaction where one firm purchases a dominant stake of another firm without combining the assets of the firms involved.

According to Weston and Weaver (2004), from economic perspective, mergers can be categorized based on occurrence of merger at different level of the firm's operation whether it starts its economic operation, manufacturing or production, distribution (wholesale or retail) ending with the final consumers. The three broad types of mergers are vertical mergers, horizontal mergers and conglomerate mergers.

Weaver (2004) explained the three broad types as follows: 
Vertical mergers take place between firms at "different stages of production". This is more obvious when the merging firm's business operations involve relationship between buyer and seller. In contrast to vertical mergers, horizontal mergers entail firms (two or more) that operate and compete in the same type of product operations. Advocates of this type of merger claim that horizontal mergers realize economies of scale. A vital issue associated with horizontal mergers is market concentration where number of firms is reduced which could lead to monopoly power.

Finally, conglomerate mergers occur when the combining firms operate in different unrelated industries. That is, there is no "buyer-seller relationship" between firms engaged in the merger. There are two ways in which the acquirer may take over the target firm; either through statutory merger or purchase of assets. Under the statutory merger, the acquiring firm takes statutorily over the target firm where the shares of the latter are exchanged for the shares of the buying firm, followed by the legal dissolution of the target company. In purchase of assets method, the acquiring firm might purchase the assets and become legally responsible for the liabilities of the target firm.

\subsection{The Concept of Service Quality}

Service quality has been defined in the literature as a measure of the perceived value customers place on services received (Cunningham \& Young, 2002). Customers are said to compare service perception to service expectations when judging the quality of a service offered by a firm. In today's competitive banking environment delivering service of superior quality serves as key for success (Samli \& Frohlich, 1992).

Service quality has been linked with customer satisfaction within the banking industry (e.g. Avkiran, 1994; Blanchard \& Galloway, 1994). Proponents of this theory include researchers such as Yi, (1990); Bloemer, et al (1998); Bastos and Gallego (2008); Chai et al. (2009). Bastos and Gallego (2008) provide evidence that customer service quality directly affects the positive behavioral intentions. Today's customers face a growing range of choice in the products and services they can buy. Customers will normally choose the offer that maximizes the delivered value and provide the highest satisfaction. Thus it is of utmost important that companies understand the determinants of customer value and satisfaction in order to flourish.

Increased customer satisfaction leads to behavioral outcomes such as commitment, intent to stay customer retention, creation of a mutually rewarding relationship (bond) between the service provider and the user, increased customer tolerance for service failures and positive word-of mouth advertising about the organization (Gounaris et al., 2003; Reichheld, 1996; Newman, 2001). Only customer-centered companies that can deliver superior value to their target customers will win or survive in the market. Those companies will be adept at developing customers, not just developing products. They will be skillful in marketing engineering, not just engineering (Hinson et al., 2006). There is a growing body of theoretical and empirical knowledge on the relationships among customer satisfaction, customer loyalty, and profitability (see Heskett et al., 1994: Nelson et al., 1992; Rust \& Zahorik, 1991; Storbacka et al., 1994). An empirical study conducted by Hallowel (1995) that customer satisfaction, customer loyalty, and profitability are related to one another. Thus:

Customer satisfaction $<$.. $>$ customer loyalty $<$.. $>$ profitability.

Hence in the light of the service-profit chain proposed by Heskett et al. (1994) and the empirical work by Hallowell (1995), it can be said that it is highly probable for a firm (bank) that provide superior services to win the lifetime loyalty of their customers and improve profitability through growth in customer base and market share.

\subsection{Measuring Service Quality}

The measurement of service quality is traditionally based on the concept of perception - expectation gap analysis Gronroos, (1994). Expectations are viewed as desires or wants of customers; i.e. what they feel a service provider 'should' offer rather than 'would' offer (Parasuraman et al., 1988). Service in this sense comprises a complex bundle of explicit and implicit attributes. The array of service quality models in the literature stem from the disagreements in the nature and contents of service quality dimensions Suuroja (2003). For example Gronroos (1984) divided customer perception of service process into two dimensions;

- Technical quality - what customers get.

- Functional quality - how customers get what they get.

Lethinen and Lehtinen (1991) also proposed a three dimensional view of service quality as follows:

- $\quad$ Physical quality-physical environment.

- Interactive quality - provider interaction/customer participation fit. 
- $\quad$ Corporate quality - corporate image.

Parasuraman et al. (1988) proposed a more specific tool of service quality dimensions. According to them the overall evaluation of service quality derives from the evaluation along five dimensions;* reliability - ability to perform the promised service dependably and accurately.

Assurance - Knowledge and courtesy of employees and their ability to inspire trust and confidence.

Tangibles - physical facilities, equipments and appearance of personnel.

Responsiveness - willingness to help customers and provide prompt service.

Empathy - caring, individualized attention that the firm provides to its customers.

Service quality is an average of the expectancy - performance gap along these five dimensions.

Nyeck et al. (2002) reviewed 40 articles that made use of the SERVQUAL measuring tool and concluded that although the tool has its criticisms it remains the most complete attempt to conceptualize and measure service quality.

\section{Methodology}

This chapter presents the methodology of the study. It covers the research design, population, sampling techniques, data collection procedures and data analysis.

\subsection{Research Design}

The study is both a descriptive and explanatory in purpose as it seeks to describe customer perceived service quality and also explain the relationship between service quality and efficiency as banks in Ghana expand their operations through mergers and acquisitions.

\subsection{The Choice of Bank}

The objective of the study is to assess how M \& A has impacted service quality of selected commercial banks in Ghana, particularly following the 2008 bank recapitalization. This presupposes that the data for the study should cover both pre and post M \& A periods, preferably starting from 2008. The two banks selected, Ecobank and Access Bank are two of the first banks to undergo consolidation after the 2008 bank recapitalization policy. What makes them more important for this research is the fact that unlike Bank of Africa, these two banks were in operation as of 2008. However, Bank of Africa commenced operation in Ghana in 2011, same year as when it combined operations with Amalgamated Bank of Ghana.

\subsection{Population and Sample Size}

The population for the study was individual customers of the selected Banks (Ecobank and Access Bank) located in the Greater Accra Region. Customers of commercial banks include all of the various categories of customers of the banking industry. This makes the selected banks unique case for our study. The population is a composition of individuals of varied background characteristics in terms of sex, ages, level of education and profession. A total sample size of 80 customers was selected for the study.

\subsection{Sampling Technique}

- Different Bank branches in Accra for each bank were used for sampling to minimize location bias.

- Also customers who had been with their respective banks for at least 4 years as of the time of the survey were targeted. This is because the M \& A exercise for the banks under study occurred between 2011 and early 2012 and such customers will be in a better position to provide more reliable data.

\subsection{Data Measuring Instrument}

The SERVQUAL model of Kumar, Kee and Manshor (2009) for measuring service quality in banks, based on four dimensions; Tangibility, Reliability, Responsiveness and Convenience, was adopted for this study. The original SERVQUAL model Paarasuraman et al. (1991) measures service quality along the lines of empathy, reliability, responsiveness, tangibility and assurance. A fifth dimension, 'range of products/services', as suggested by Hinson et al (2006) in the context of bank services was included. Convenience and product/services range are two important factors that in our view cannot be overlooked in the context of merging banks. Bank consolidations will invariably result in additional branches and broader spectrum of product/services which can potentially impact on customers perceived service quality.

The original instruments were fourteen (14). However, for the pre and post - merger service quality assessment our data collection instruments consisted of twenty eight (28) items. 
For each dimension customers are required to indicate their expectation (E) and perception (P) on a five (5) points likert scale. Expectation-Perception gap scores are computed and analysed to assess service quality. Thus, based on the expectancy-disconfirmation paradigm, if $\mathrm{E}>\mathrm{P}$, the customer is dissatisfied and if $\mathrm{E}<\mathrm{P}$ the customer is satisfied Parasuraman et al. (1991a).

\subsection{Indicators of overall Service Quality}

In this study, overall service quality is conceptualized to be dependent on the dimensions of service quality and is an average of the gap scores of the dimensions. Hence, overall service quality is computed as follows:

\begin{tabular}{lcc}
\hline Gap Scores & Post M \& A & Pre M \& A \\
\hline Average Convenience gap score & $\sum(E-P) / 3$ & $\sum(E-P) / 3$ \\
Average Product/Service range gap score & $\sum(E-P) / 3$ & $\sum(E-P) / 3$ \\
Average Tangible gap score & $\sum(E-P) / 2$ & $\sum(E-P) / 2$ \\
Average Reliability gap score & $\sum(E-P) / 3$ & $\sum(E-P) / 3$ \\
Average Competence gap score & $\sum(E-P) / 3$ & $\sum(E-P) / 3$ \\
TOTAL & $\sum(E-P) / 3$ & $\sum(E-P) / 3$ \\
AVERAGE (= Total /5) UNWEIGHTED SERVQUAL SCORE & Total 5 & Total/5 \\
\hline
\end{tabular}

\subsection{Data Gathering Technique}

Service quality data in the form of primary data was collected by means of questionnaire, using SERVQUAL model (Parasuraman et al., 1988) as a guide. The questionnaire consisted of three parts; A (customer profile), Part B (customer banking profile) and Part C (45 items on customer expectations and perceptions of service quality before and after merger). A total of 80 questionnaires were administered; 40 to Ecobank customers, 40 to Access Bank customers.

\section{Data Analysis}

The study employed quantitative data analysis. ANOVA (analysis of variance) and T-test (one tail) techniques were used. For each service quality dimension, ANOVA was used to test the differences among means for pre acquisition perception, post - acquisition perception and expectation. The T-test was used to further probe the significance of the pre - acquisition gap (i.e. pre-acquisition perception verses expectation) and post - acquisition gap (i.e. post - acquisition perception and expectation) for each service quality dimension.

This chapter deals with the analysis, interpretation and presentation of both primary and secondary data collected. It begins with primary data analysis followed by secondary data analysis.

The primary data analysis includes profile of respondents (gender, age, and educational level), the perception and expectation gaps of service quality dimensions and overall service quality. The foregoing analyses are done on pre-acquisition and post-acquisition data of the two banks under consideration; Ecobank Ghana and Access Bank of Ghana. Results thereof are presented in tabular forms.

Statistical tools employed in the primary data analysis are Anova (single factor) analysis and t-Test) Paired Two Samples for Mean). Anova allowed for significance testing between and within Means of more than two observations. For example for each service quality dimensions (say convenience) it is possible to test significance of Mean differences for pre-acquisition service perception, post-acquisition service perception and service expectations. Whereas the Anova gives us a general result of pre-and post - acquisition service level for convenience, the $\mathrm{t}$-Test is able to tell us whether pre-acquisition convenience was better than post - acquisition convenience or otherwise.

\subsection{Profile of Respondents}

To help achieve the set objectives of the study, data was collected on the background characteristics of the respondents. This data is summarized in Table 4.1 below. 
Table 1. Background information of respondents

\begin{tabular}{|c|c|c|c|c|}
\hline \multirow[b]{2}{*}{ DESCRIPTION CATEGORY } & \multicolumn{2}{|c|}{ ECOBANK } & \multicolumn{2}{|c|}{ ACCESS } \\
\hline & FREQ & $\%$ FREQ & FREQ & \% FREQ \\
\hline \multicolumn{5}{|l|}{ Gender } \\
\hline Male & 23 & 57.5 & 21 & 52.5 \\
\hline Female & 17 & 42.5 & 19 & 47.5 \\
\hline Total & 40 & 100.0 & 40 & 100 \\
\hline \multicolumn{5}{|l|}{ Age } \\
\hline Below 20 Years & 1 & 2.5 & 0 & 0.0 \\
\hline $20-29$ & 4 & 10.0 & 12 & 30.0 \\
\hline $30-39$ & 16 & 40.0 & 13 & 32.5 \\
\hline $40-49$ & 11 & 27.5 & 10 & 25.0 \\
\hline $50-59$ & 6 & 15.0 & 3 & 7.5 \\
\hline 60 and above & 2 & 5.0 & 2 & 5.0 \\
\hline Total & 40 & 100.0 & 40 & 100.0 \\
\hline \multicolumn{5}{|l|}{ Education } \\
\hline Primary & 5 & 12.5 & 0 & 0.0 \\
\hline Secondary & 8 & 20.0 & 11 & 27.5 \\
\hline Graduate & 17 & 42.5 & 20 & 50.0 \\
\hline Post-graduate & 10 & 25.0 & 9 & 22.5 \\
\hline Total & 40 & 100.0 & 40 & 100.0 \\
\hline
\end{tabular}

Source: Field Survey, (2015).

Table 1 shows that 23 out of 40 (representing 57\%) Ecobank respondents were male and 17 (i.e. $42.5 \%$ ) were female. Gender distributions for Access Bank respondents followed similar trend; 21 out of 40 (i.e. 52.5\%) were male and 19 (representing 47.5\%) were female. Statistical analysis shows a strong positive correlation $(+1)$ between gender distributions of the two banks.

Table 1 also indicates that 37 out of 40 Ecobank respondents (representing 92.5\%) were within the working class age group (20-59years) and the remaining 7.5\% were either between 20years or above 60years. Similarly, 38 out of 40 (representing 95\%) respondents of Access Bank were within the working class age group. The remaining 5\% were over 60years. This follows a simple logic that the active and working population of Ghana is expected to constitute the largest group of Bank customers.

Another indication of Table 1 is that 27 out of 40 Ecobank respondents (representing 68\%) and 29 out of 40 Access Bank respondents (representing 72.5\%) were highly educated (graduates or post-graduates). This is a reflection of the demographics of the local residents where the sampling was conducted.

\subsection{Anova and T-tests for Service Quality Dimensions}

Table 2. Anova and t-tests for convenience (Ecobank)

\begin{tabular}{llllllllll}
\hline Convenience & Mean & Count & Std. D & \multicolumn{2}{l}{ Anova(Single-factor) } & & t-test (one tail) & \\
\cline { 7 - 10 } & & & & F-sat & F-crit & t-stat & t-crit & Df \\
\hline Expectation & 3.300 & 40 & 1.043 & & & & \\
Perception-Pre & 2.400 & 40 & 1.057 & 48.283 & 3.074 & -4.389 & 1.685 & 39 \\
Perception-Post & 4.425 & 40 & 0.594 & & & 7.579 & 1.685 & 39 \\
\hline
\end{tabular}

Source: Field Survey, (2015).

Table 2 above shows the analysis of Means for pre and post - acquisition perception verses expectation of service quality with regards to convenience at Ecobank. Single factor analysis of variance between and within scores revealed a significant difference among the three Means. Paired sample t-test for Means further revealed significant pre- acquisition gap for convenience (i.e. difference between pre-acquisition perception and expectation) of -0.9 (2.400-3.300) and a significant post-acquisition gap (difference between post- acquisition perception of 1.125 (4.425-3.300). The negative pre- acquisition gap indicates that Ecobank customers' 
perception of service quality with regards to convenience fall short of their expectation. The positive postacquisition convenience gap however indicates that after the $M \&$ A exercise Ecobank is meeting the banking needs of the customers as far as convenience is concerned.

Table 3. Anova and t-tests for convenience (Access Bank)

\begin{tabular}{|c|c|c|c|c|c|c|c|c|}
\hline \multirow[b]{2}{*}{ Convenience } & \multirow[b]{2}{*}{ Mean } & \multirow[b]{2}{*}{ Count } & \multirow[b]{2}{*}{ Std. D } & \multicolumn{2}{|c|}{ Anova (single-factor) } & \multicolumn{3}{|c|}{ t-test (one tail) } \\
\hline & & & & F-sat & F-crit & t-stat & t-crit & Df \\
\hline Expectation & 3.375 & 40 & 0.774 & & & & & \\
\hline Perception - Pre & 2.325 & 40 & 0.944 & 75.425 & 3.074 & -6.736 & 1.685 & 39 \\
\hline Perception - Post & 4.450 & 40 & 0.552 & & & 7.654 & 1.685 & 39 \\
\hline
\end{tabular}

Source: Field Survey (2015).

Table 3 above shows the analysis of means for pre- and post - acquisition perception verses expectation of service quality with regard to convenience at Access Bank. As it was in the case of Ecobank, single factor analysis of variance between and within scores revealed a significant difference among the three Means. Paired sample t-test for Means further revealed a significant pre-acquisition gap for convenience of -1.05 (2.325-3.375) and a significant post - acquisition gap of $1.075(4.450-3.375)$. The negative pre-acquisition gap indicates that customers' perception of service quality with regards to convenience fall short of their expectation at Access Bank. Again, just like Ecobank, it appears that the banking needs of customers at Access Bank as far as convenience is concerned was not being met before the M\&A exercise but the situation reversed after the merger. Anova and t-tests for Service Quality with regard to Product/Service Range

Table4. Anova and t-tests for products/services range (Ecobank)

\begin{tabular}{lcccccccc}
\hline & & & & \multicolumn{3}{l}{ Anova (single-factor) } & t-test (one tail) \\
\cline { 7 - 9 } Convenience & Mean & Count & Std. D & F-sat & F-crit & t-stat & t-crit & Df \\
\hline Expectation & 3.050 & 40 & 0.846 & & & & & \\
Perception-Pre & 3.575 & 40 & 0.781 & 7.945 & 3.074 & 3.201 & 1.685 & 39 \\
Perception-Post 3.700 & 40 & 0.687 & & & 5.124 & 1.685 & 39 \\
\hline
\end{tabular}

Source: Field Survey (2015).

Table 4 above shows the analysis of Means for pre-and post-acquisition perception and expectation of service quality with regard to product and service range at Ecobank. Single factor analysis of variance between and within scores revealed a significant difference among the three Means. Paired sample t-test for Means further revealed significant pre-acquisition gap of 0.525 (3.575-3.050) and a significant post - acquisition gap of 0.65 (3.700-3.050). Both pre-acquisition and post - acquisition gaps were positive, suggesting customer delight for the range of services and products offered by the bank, before M\&A exercise.

Table 5. Anova and t-tests for products/services range (Access Bank)

\begin{tabular}{|c|c|c|c|c|c|c|c|c|}
\hline \multirow[t]{2}{*}{ Convenience } & \multirow[t]{2}{*}{ Mean } & \multirow[t]{2}{*}{ Count } & \multirow[t]{2}{*}{ Std. D } & \multicolumn{2}{|c|}{ Anova (single-factor) } & \multicolumn{3}{|c|}{ t-test (one tail) } \\
\hline & & & & F-sat & F-crit & t-stat & t-crit & Df \\
\hline Expectation & 3.500 & 40 & 0.816 & & & & & \\
\hline Perception-Pre & 3.725 & 40 & 0.751 & 1.277 & 3.074 & 1.388 & 1.685 & 39 \\
\hline Perception-Post & 3.750 & 40 & 0.742 & & & 2.037 & 1.685 & 39 \\
\hline
\end{tabular}

Source: Field Survey, (2015).

Table 5 above shows the analysis of Means for pre- and post-acquisition perception verses expectation of service quality with regards to product and services range at Access Bank. Single factor analysis of variance between 
and within scores revealed no significant difference among the three Means. Paired sample t-test for Means further revealed an insignificant pre-acquisition gap of 0.225 (3.725-3.5) but a significant post-acquisition gap (i.e. difference between post-acquisition perception and expectation) of 0.25 (3.75-3.5). The insignificant pre-acquisition gap indicates that although customers of Access Bank perceive the range of products and services offered before the merger as better than what they expected, the difference is not statistically significant. The significant post-acquisition gap however indicates that customers' need at Access bank, as far as range of products and services offered are concerned, are being met after the merger.

Table 6. Anova and t-tests for Tangibility (Ecobank)

\begin{tabular}{lcccccccc}
\hline Convenience & Mean & Count & Std. D & \multicolumn{2}{l}{ Anova (single-factor) } & \multicolumn{3}{c}{ t-test (one tail) } \\
\cline { 6 - 9 } & & & & F-sat & F-crit & t-stat & t-crit & Df \\
\hline Expectation & 3.550 & 40 & 0.677 & & & & & \\
Perception-Pre & 3.575 & 40 & 0.675 & 0.129 & 3.074 & 0.255 & 1.685 & 39 \\
Perception-Post 3.625 & 40 & 0.667 & & & 1.000 & 1.685 & 39 \\
\hline
\end{tabular}

Source: Field Survey, (2015).

Table 6 above shows the analysis of Means for pre- and post-acquisition perception verses expectation of service quality with regards to tangibility at Ecobank. Single factor analysis of variance between and within scores revealed no significant difference among the three Means. Paired sample t-test for Means further revealed that both pre-acquisition and post-acquisition scores for tangibility, albeit in excess, were not statistically different from customers' expectation. The positive gaps in both cases indicate that customers' needs with regards to tangibility at Ecobank are being met and are therefore satisfied.

Table 7. Anova and t-tests for tangibility (Access Bank)

\begin{tabular}{|c|c|c|c|c|c|c|c|c|}
\hline \multirow[t]{2}{*}{ Convenience } & \multirow[t]{2}{*}{ Mean } & \multirow[t]{2}{*}{ Count } & \multirow[t]{2}{*}{ Std. D } & \multicolumn{2}{|c|}{ Anova (single-factor) } & \multicolumn{3}{|c|}{ t-test (one tail) } \\
\hline & & & & F-sat & F-crit & t-stat & t-crit & Df \\
\hline Expectation & 3.775 & 40 & 0.768 & & & & & \\
\hline Perception-Pre & 3.775 & 40 & 0.698 & 0.016 & 3.074 & 0.000 & 1.685 & 39 \\
\hline \multicolumn{2}{|c|}{ Perception-Post 3.800} & 40 & 0.723 & & & 0.330 & 1.685 & 39 \\
\hline
\end{tabular}

Source: Field Survey, (2015).

Table 7 above shows the analysis of Means for pre- and post-acquisition perception verses expectation of service quality with regard to tangibility at Access Bank. Just like the case of Ecobank, single factor analysis of variance between and within scores revealed no significant difference among the three Means. Also paired sample t-test for Means further revealed that both pre-acquisition and post - acquisition scores for tangibility were not statistically different from customers' expectation. Again, in both cases, customers' need with regards to tangibility at Access Bank is being met.

Table 8. Anova and t-tests for reliability (Ecobank)

\begin{tabular}{|c|c|c|c|c|c|c|c|c|}
\hline \multirow[t]{2}{*}{ Convenience } & \multirow[t]{2}{*}{ Mean } & \multirow[t]{2}{*}{ Count } & \multirow[t]{2}{*}{ Std. D } & \multicolumn{2}{|c|}{ Anova (single-factor) } & \multicolumn{3}{|c|}{ t-test (one tail) } \\
\hline & & & & F-sat & F-crit & t-stat & t-crit & Df \\
\hline Expectation & 4.475 & 40 & 0.677 & & & & & \\
\hline Perception-Pre & 3.675 & 40 & 0.675 & 12.682 & 3.074 & -4.207 & 1.685 & 39 \\
\hline Perception-Post & 4.475 & 40 & 0.667 & & & 0.000 & 1.685 & 39 \\
\hline
\end{tabular}

Source: Field Survey, (2015).

Table 8 above shows the analysis of Means for pre- and post-acquisition perception verses expectation of service quality with regards to reliability at Ecobank. Single factor analysis of variance between and within scores revealed a significant difference among the three Means. Paired sample t-test for Means further revealed significant negative pre-acquisition gap for reliability of -0.8 (3.675-4.475) and zero post-acquisition gap. The negative pre-acquisition gap indicates customers' dissatisfaction with regard to service reliability prior to the 
bank's integration. The zero post - acquisition gap however indicates that after the M\&A exercise Ecobank is now meeting the banking needs of its customers as far as reliability is concerned.

Table 9. Anova and t-tests for reliability (Ecobank)

\begin{tabular}{lcccccccc}
\hline Convenience & Mean & Count & Std. D & & \multicolumn{3}{l}{ Anova (single-factor) } & \multicolumn{3}{l}{ t-test (one tail) } \\
\cline { 5 - 9 } & & & & F-sat & F-crit & t-stat & t-crit & Df \\
\hline Expectation & 4.275 & 40 & 0.716 & & & & & \\
Perception-Pre & 4.300 & 40 & 0.608 & 0.245 & 3.074 & 0.138 & 1.685 & 39 \\
Perception-Post 4.375 & 40 & 0.667 & & & 0.703 & 1.685 & 39 \\
\hline
\end{tabular}

Source: Field Survey, (2015).

Table 9 above shows the analysis of Means for pre- and post-acquisition perception verses expectation of service quality with regards to reliability at Access Bank. Single factor analysis of variance between and within scores revealed no significant difference among the three Means. Paired sample t-test for Means further revealed no significant difference for both pre- and post-acquisition gaps of 0.025 (4.3-4.275) and 0.10 (4.735-4.275). The results suggest that although there is some favorable (positive) difference between customers' perception and expectation scores with regards to reliability of services, both pre and post- acquisition, the differences are not statistically significant.

Table 10. Anova and t-tests for responsiveness (Ecobank)

\begin{tabular}{lcccccccc}
\hline Convenience & Mean & Count & Std. D & & \multicolumn{2}{l}{ Anova (single-factor) } & \multicolumn{2}{l}{ t-test (one tail) } \\
\cline { 6 - 9 } & & & & F-sat & F-crit & t-stat & t-crit & Df \\
\hline Expectation & 4.525 & 40 & 0.599 & & & & & \\
Perception-Pre 3.700 & 40 & 0.823 & 11.719 & 3.074 & -5.167 & 1.685 & 39 \\
Perception-Post 4.100 & 40 & 0.841 & & & -2.889 & 1.685 & 39 \\
\hline
\end{tabular}

Source: Field Survey, (2015).

Table 10 above shows the analysis of Means for pre- and post-acquisition perception verses expectation of service quality with regard to responsiveness at Ecobank. Single factor analysis of variance between and within scores revealed a significant difference among the three Means. Paired sample t-test for Means further revealed significant pre-acquisition gap for responsibility of - 0.825 (3.7-4.525) and a significant post - acquisition gaps suggest that, with regards to responsiveness, Ecobank customers did not meet their service quality needs prior to the acquisition of TTB, and still are not meeting those needs even after acquisition.

Table 11. Anova and t-tests for responsiveness (Access Bank)

\begin{tabular}{lcccccccc}
\hline Convenience & Mean & Count & Std. D & & \multicolumn{2}{l}{ Anova (single-factor) } & \multicolumn{2}{l}{ t-test (one tail) } \\
\cline { 6 - 9 } & & & & F-sat & F-crit & t-stat & t-crit & Df \\
\hline Expectation & 4.300 & 40 & 0.687 & & & & & \\
Perception-Pre 3.800 & 40 & 0.823 & 4.233 & 3.074 & -3.203 & 1.685 & 39 \\
Perception - Post 4.125 & 40 & 0.822 & & & -1.267 & 1.685 & 39 \\
\hline
\end{tabular}

Source: Field Survey (2015).

Table 11 above shows the analysis of Means for pre- and post - acquisition perception verses expectation of service quality with regard to responsiveness at Access Bank. Single factor analysis of variance between and within scores revealed a significant difference among the three Means. Paired sample t-test for Means further revealed significant pre-acquisition gap for responsibility of -0.5 (3.8-4.3) and significant post - acquisition gap of -0.175 (4.125-4.3). Similar to Ecobank the unfavorable (negative) pre-and post - acquisition gaps suggest that, with regard to responsiveness, Access Bank customers did not meet their service quality needs prior to the acquisition of Intercontinental bank, and still are not meeting those needs even after acquisition. 


\subsection{Overall Servqual Scores}

The difference (gap) between a customer's perception and expectation score for each servqual dimension is an estimate of the level of service quality with regards to that dimension. The Mean gap for all customers gives a balanced impression of the level of service quality provided to all customers. Tables $4.12 \& 4.13$ are summaries of the Mean scores and Mean gaps of service quality dimensions under study for Ecobank and Access Bank respectively.

Table 12. Overall servqual scores (ECOBANK)

\begin{tabular}{|c|c|c|c|c|c|c|c|c|c|}
\hline & & Expectation & Perception & (Pre) & $\begin{array}{l}\text { Percep } \\
\text { (Post) }\end{array}$ & Perception & & & Gap \\
\hline & & Std. & & Std. & & & Std. & & \\
\hline Dimension & Mean & $\mathrm{D}$ & Mean & & Mean & $\mathrm{D}$ & & Pre & Post \\
\hline Convenience & 3.300 & 1.042 & 2.400 & 1.057 & 4.425 & & 0.594 & -0.900 & 1.125 \\
\hline Product Range & 3.050 & 0.845 & 3.575 & 0.780 & 3.700 & & 0.686 & 0.525 & 0.650 \\
\hline Tangibility & 3.550 & 0.677 & 3.575 & 0.675 & 3.625 & & 0.667 & 0.025 & 0.075 \\
\hline Reliability & 4.475 & 0.640 & 3.675 & 1.047 & 4.475 & & 0.715 & -0.800 & 0.000 \\
\hline Responsiveness & 4.525 & 0.598 & 3.700 & 0.822 & 4.100 & & 0.841 & -0.825 & -0.425 \\
\hline Average & -0.395 & & & & & & & & 0.285 \\
\hline
\end{tabular}

Source: Field Survey, (2015).

An overall average negative gap (-0.395) for pre-acquisition service quality dimensions suggests that generally, customers' perception of service quality level at Ecobank prior to the bank's consolidation with The Trust Bank in 2011 falls short of what they expected. The positive post - acquisition gap (0.285) however connotes a higher perception over expectation after consolidation. Generally there has been an improvement in the quality of service at Ecobank following the merger and acquisition exercise as per the results.

It is however worth noting that the overall perception of improvement in service level as indicated above have been driven at varying degrees by the various dimensions considered. Convenience was the strongest driver $2.025(1.125+0.9)$ followed by responsiveness $0.4(-0.425+0.825)$, Product range $0.125(0.65-0.525)$, reliability $0.08(0.0-0.8)$ and finally tangibility $0.05(0.075-0.025)$. This suggests that customers are now experiencing improved service quality with respect to the various service dimensions in the order as aforementioned.

Although customers' perception of service quality has generally improved after the acquisition, their perception with regard to responsiveness is still lagging behind expectation. This shows that there is room for improvement with regard to the bank's responsiveness towards customers.

Table 13. Overall servqual scores (ACCESS BANK)

\begin{tabular}{|c|c|c|c|c|c|c|c|c|c|c|c|}
\hline & \multicolumn{3}{|c|}{ Expectation } & \multicolumn{2}{|l|}{ Perception } & (Pre) & $\begin{array}{l}\text { Percep } \\
\text { (Post) }\end{array}$ & Perception & & & Gap \\
\hline & & & Std. & & & Std. & & & Std. & & \\
\hline Dimension & Mean & $\mathrm{D}$ & & Mean & $\mathrm{D}$ & & Mean & $\mathrm{D}$ & & Pre & Post \\
\hline Convenience & 3.375 & & 0.774 & 2.325 & & 0.944 & 4.450 & & 0.552 & -1.050 & 1.075 \\
\hline Product Range & 3.500 & & 0.816 & 3.725 & & 0.750 & 3.750 & & 0.742 & 0.225 & 0.250 \\
\hline Tangibility & 3.775 & & 0.760 & 3.775 & & 0.695 & 3.800 & & 0.723 & 0.000 & 0.025 \\
\hline Reliability & 4.275 & & 0.715 & 3.300 & & 0.607 & 4.375 & & 0.667 & 0.025 & 0.100 \\
\hline Responsiveness & 4.300 & & 0.686 & 3.800 & & 0.822 & 4.125 & & 0.822 & -0.500 & -0.175 \\
\hline Average & -0.260 & & & & & & & & & & \\
\hline
\end{tabular}

Source: Field survey (2015). 
An overall average negative gap (-0.60) for pre-acquisition service quality dimensions suggests that generally customers' perception of service quality level at Access Bank prior to the bank's M \& A exercise with Intercontinental in 2011 falls short of what they expected. The positive post-acquisition gap (0.255) however indicates a higher perception over expectation after the M\&A, just like Ecobank. Generally there has been an improvement in the quality of service at Access Bank following the merger and acquisition exercise as per the results shown in Table 4.13.

Similar to the case of Ecobank convenience at Access Bank was the strongest determinant $2.125(1.075+1.059)$ followed by responsiveness $0.325(0.5-0.175)$, reliability $0.075(0.10-0.025)$, and finally Product range and tangibility, both 0.0125 . This suggests that customers are now experiencing better service quality with respect to the various service dimensions. Although customers' perception of service quality has generally improved after the acquisition, their perception with respect to responsiveness is still falling short of expectation. This shows that there is still room for improvement with regards to the Access banks' responsiveness towards customers.

\section{Conclusion}

The study reveals that before the M \& A exercise both Ecobank and Access Bank showed an overall shortfall in customers' perception relative to their expectation of service quality. The situation however reversed after the M \& A exercise, suggesting that the exercise has favorably impacted the overall quality of service delivered by the two selected banks.

In terms of the various service quality dimensions considered, convenience was the key driver of service quality followed by responsiveness as indicated by their relatively wider margin of change. This suggests that customers are experiencing marked improvement in the foregoing service quality dimensions as a result of the $\mathrm{M} \& \mathrm{~A}$. Although responsiveness has improved remarkably after the exercise, customers' perception still falls short of expectation. This suggests that there is still room for improvement with regards to responsiveness.

The study further reveals both banks are meeting customers' perception of tangibility, both before and after the M \& A and that the exercise has not significantly affected this perception. This could suggest that respondents do not place much premium on 'tangibility' and thus are indifferent when it comes to scoring for both pre and post $M \&$ A performances or both banks are actually performing just well and the $M$ \& A exercise has actually not made any significant impact.

In terms of range of products and services being offered, the study shows a significant improvement for both banks after M \& A. Thus, indicating a favorable improvement in customer' perception with regard to that service dimension as a result of the exercise. In terms of reliability, the study shows that perception of Ecobank customers has shifted from falling short of expectations before the $M \&$ A to just meeting it after the exercise, indicating a favorable effect thereof. Reliability at Access Bank has however, been on the favorable side before and after the M \& A and has not significantly changed with the exercise. This suggests that Access Bank provides reliable services to their customers and the $M \&$ A exercise has not significantly made a difference.

The researchers conclude from the aforementioned findings that mergers and acquisitions offer superior growth option for banks through improvement in services delivery and thus contribute to promote economic efficiency.

\subsection{Recommendations}

- Managers should pay particular attention to all service quality dimensions and institute appropriate measures to deal with factors that militate against the delivery of services that delight customers.

- Banks can work towards a synergy-based merger plan that could take shape with minimization of technology-related expenditure as a goal.

- There is also a need to note that merger or large size is just a facilitator, but no guarantee for improved profitability on a sustained basis.

- Banks need to take advantage of this fast changing environment, where product life cycles are short, time to market is critical and first mover advantage could be a decisive factor in deciding who wins in future. By merging, the new company is theoretically provided with access to more customers. The combined skills of the marketing departments will then be able to sell these products more effectively. The net result is that shareholder value is increased. 


\section{References}

Avkiram, N. K. (1994). Developing an instrument to measure customer service quality in branch banking. International Journal of Bank Marketing, 12(6), 10-18.

Bastos, J. A. R., \& Gallego, P. M. (2008). Pharmacies Customer Satisfaction and Loyalty: A Framework Analysis. Journal of Marketing. Universidad de Salamanca

Blanchard, R., \& Galloway, R. (1994). Quality in retail banking. International Journal of Service Industry Management, 5(4), 5-23.

Brownbridge, M., \& Gockel, A. F. (1995). The impact of Financial Sector Policies on Banks in Ghana. IDS, Sussex.

Chai, K. H., Ding, Y., \& Xing, Y. (2009). Quality and Customer Satisfaction Spillovers in the Mobile Phone. Industry Service Science, 1(2), 93-106.

Chung, K. S., \& Hoag, S. E. (1990). Mergers, Restructuring and Corporate Control. Prentice-Hall International.

Cunningham, L. F., \& Young, C. E. (2002). Cross-Cultural Perspectives of Science Quality and Risk in Air Transportation. Journal of Air Transportation, 1, 3-26.

Gaughan, P. A. (2007). Merger, Acquisitions and Corporate Restructurings (4th ed.). New Jersey: John Wiley \& Sons Inc.

Gounaris, S. P., Stathakopoulos, V., \& Athanassopoulos, A. D. (2003). Antecedents to perceived service quality: An exploratory study in the banking industry. International Journal of Bank Marketing, 21(4) 168-190.

Gronroos. (1994). From Marketing Mix to Relationship Marketing: Towards Paradigm Shift Marketing ASIA. Australia Marketing Journal, 2(1), 9-30.

Heskett, J. L., Jones, T. O., Loveman, G. W., Sasser, W. E. Jr., \& Schlesinger, L. A. (1994). Putting the service profit chain to work. Harvard Business Review, 105-11.

Hinson, R., Mohammed, A., \& Mensah, R. (2006). Determinants of Ghanaian Bank Service Quality in a Universal Banking Dispensation. Bank and Banking Systems, 1(2).

Lehtinen, \& Lehtinen. (1991). Two approaches to Service Quality Dimensions. Service Industries Journal, 11(3) 287-293.

Nelson, E., Rust, R. T. Zahorik, A. J., Rose, R., Batalden, P., \& Siamanski, B. A. (1992). Do patient perceptions of quality relate to hospital financial performance. Journal of Health Care Marketing, 42-49.

Newman, K. (2001). Interogating SERVQUEL; A critical assessment of Service Quality Measurement in a high street retail bank. International Journal of Bank Marketing, 19(3), 126-139.

Nyeck, S., Morales, M., Ladhari, R., \& Pons, F. (2002). Ten years of service quality measurement: reviewing the use of the SERVQUEL instrument. Cuadernos de Dffusion, 7(13), 101-107.

Okonkwo, C. (2004). Legal Framework for Mergers and Acquisitions (pp. 128). Abuja: Central Bank of Nigeria, West Africa Institute for Financial and Economic Management.

Parasuraman, A., Zeithaml, V. A., \& Berry, L. L. (1988). SERQUEL: A multiple-item scale for measuring consumer perceptions of service quality. Journal of Retailing, 64.

Pilloff, S. J., \& Santomero, A. M. (1996). The Value Effects of Bank Mergers and Acquisition (pp. 97-107). Wharton Financial Institutions Center.

Reichheld, F. F. (1996). Learning from customer defections. Harvard Business Review, 56-69.

Roll, R. (1986). The Hubris Hypothesis of Corporate Takeovers. Journal of Business, 59(2), 197-216.

Rust, R. T., \& Zahorik, A. J. (1991). The value of customer satisfaction, Working Paper, Vanderbilt University.

Samli, C. A., \& Frohlich, C. J. (1992). Service: the competitive edge in banking. Journal of Service Marketing, 1, $15-22$.

Storbacka, K., Strandvik, T., \& Gronross, C. (1994). Managing Customer Relationship for profit: the dynamics of relationship quality. International Journal of Service Industry Management, 5(5), 21-38.

Suuroja, M. (2003). Service Quality-Main Conceptualizations and Critique. Tartu Univ. Press.

Weston, J. F. (1953). The Role of Mergers in the Growth of Large Firms. Berkeley: University of California Press. 
Yi, Y. (1990). A critical review of consumer satisfaction. In V. Zeithaml (Ed.), Review of Marketing (pp. 68-123) American Marketing Association, Chicago, IL.

\section{Copyrights}

Copyright for this article is retained by the author(s), with first publication rights granted to the journal.

This is an open-access article distributed under the terms and conditions of the Creative Commons Attribution license (http://creativecommons.org/licenses/by/3.0/). 